\title{
Transcatheter Atrial Septal Defect Device Closure - A 2.5 Years Single Center Study
}

\author{
AHMED M. NAJEB, M.Sc.; DOAA M. RAAFAT, M.D. and NAJWA A. MOHAMED, M.D. \\ The Department of Pediatrics, Faculty of Medicine, Assiut University, Assiut, Egypt
}

\begin{abstract}
Background: Atrial septal communications account for approximately $6-10 \%$ of congenital heart defects, with an incidence of 1 in 1,500 live births. The atrial septal defect (ASD) is among the most common acyanotic congenital cardiac lesions, occurring in $0.1 \%$ of births and accounting for $30-40 \%$ of clinically important intracardiac shunts.

Transcatheter device closure is advised for all symptomatic patients and also for asymptomatic patients with a Qp: Qs ratio of at least 2:1 or those with right ventricular enlargement. The timing for elective closure is usually after the 1st yr and before entry into school. Closure carried out at open heart surgery is associated with a mortality rate of $<1 \%$. Repair is preferred during early childhood because surgical mortality and morbidity are significantly greater in adulthood.
\end{abstract}

Aim of Study: Is to evaluate 2.5 years experience in transcatheter device closure of secundum atrial septal defect at the Pediatric Cardiology Unit, Assiut University Children Hospital.

Patients and Methods: The study was conducted on 62 patients [56 (90.4\%) children and $6(9.6 \%)$ adults] who underwent transcatheter secundum ASD device closure, at Pediatric Cardiology Unit of Assiut University Children Hospital from March 2014 till September 2016.

Results: Transcatheter closure of secundum ASD in children adolescents and adults has a high success rate $(98.3 \%)$ regarding the efficacy (successful closure of the defect without residual shunt) and safety (no death or major complications as cerebral embolism, cardiac tamponade, device embolization or dislodgement requiring open cardiac surgery and infectious endocarditis) during procedure, immediate and short to midterm follow-up.

Conclusion: Transcatheter closure of secundum ASD in children adolescents and adults has a high success rate $(98.3 \%)$ regarding the efficacy (successful closure of the defect without residual shunt) and safety (no death or major complications as cerebral embolism, cardiac tamponade, device embolization or dislodgement requiring open cardiac surgery and infectious endocarditis) during procedure, immediate and short to midterm follow-up.

Correspondence to: Dr. Ahmed M. Najeb, The Department of Pediatrics, Faculty of Medicine, Assiut University, Assiut, Egypt
Key Words: Atrial septal defect - Transcatheter device closure.

\section{Introduction}

ATRIAL septal communications account for approximately $6-10 \%$ of congenital heart defects, with an incidence of 1 in 1,500 live births [1]. The atrial septal defect (ASD) is among the most common acyanotic congenital cardiac lesions, occurring in $0.1 \%$ of births and accounting for $30-40 \%$ of clinically important intracardiac shunts [2]. The patent foramen ovale (PFO) is more common and is present in greater than $20-25 \%$ [3] .

Guidelines for the comprehensive assessment of the interatrial septum (IAS) have the potential to reduce variation in the quality of echocardiographic studies, guide the complete characterization of defects, standardize the measurements and techniques used to describe the anatomy and physiology, and improve the assessment of suitability for surgical and transcatheter therapies [4].

\section{Patients and Methods}

Research design: A retrospective descriptive study conducted on patients who underwent transcatheter closure of atrial septal defect at Pediatric Cardiology Unit of Assiut University Children Hospital, 2.5 Year from March 2014 to September 2016.

\section{Inclusion criteria:}

All patients that underwent transcatheter ASD device closure and were suitable for this maneuver as they had significant ASD $(\mathrm{QP} / \mathrm{QS}>1.5 / 1)$ with

\footnotetext{
Abbreviations:

ASD: Atrial Septal defect

IAS : Interatrial septum.

PFO : Patent foramen ovale.

TTE : Transthoracic echocardiography.

TEE : Transesophageal echocardiography.
} 
right ventricular volume overload and suitable for device closure (suitable septal rims of at least 4 $\mathrm{mm}$ for children and $5 \mathrm{~mm}$ for adults); according to the guidelines of American Heart Association (AHA) for cardiac catheterization and intervention in pediatrics [5].

Defects were defined as small $(>3 \mathrm{~mm}$ to $<6 \mathrm{~mm}$ ), moderate ( $>$ or $=6 \mathrm{~mm}$ to $<12 \mathrm{~mm}$ ), or large $(>$ or $=12 \mathrm{~mm})$.

\section{Exclusion criteria:}

Patients with ASD that were unsuitable for device closure due to:

- Large ASD size in relation to the weight of the patient, especially in children $(10-15 \mathrm{~kg})$ in whom the ratio of device/body weight was $>1.5$; or large ASD $>34 \mathrm{~mm}$ or deficient rims [6].

- ASD types other than secundum type.

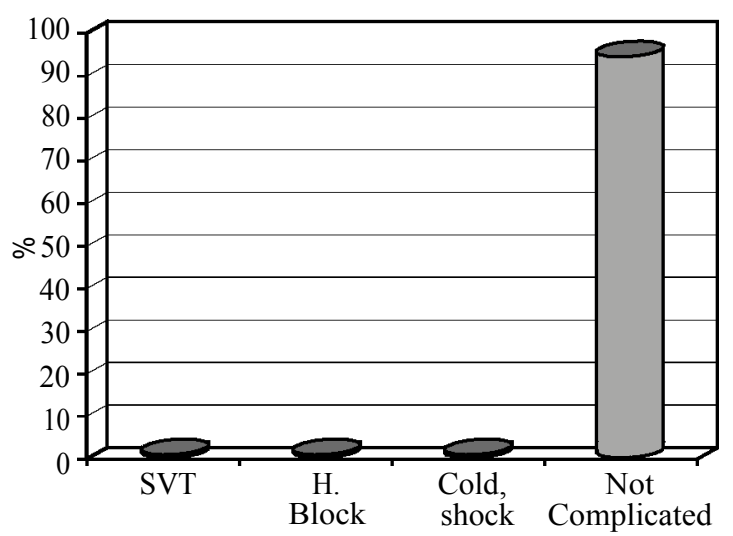

Fig. (1): Complications during the ASD device closure.
- Abnormal venous drainage.

- Associated complex cardiac anomaly.

- Severe pulmonary hypertension with ASD bidirectional or right to left shunting.

- Newborns or children below one year of age or less than $10 \mathrm{Kg}$ with asymptomatic small ASD.

\section{Results}

The study was conducted on 62 patients [56 (90.4\%) children and $6(9.6 \%)$ adults] who underwent transcatheter secundum ASD device closure, at Pediatric Cardiology Unit of Assiut University Children Hospital from March 2014 till September 2016.

The patients were grouped according to age into four groups; three children groups: From 16 years, $7-12$ years, 13-18 years and one adult group from 19-50 years.

Table (1): The demographric data of studied patients $(n=62)$.

\begin{tabular}{lll}
\hline $\begin{array}{l}\text { Demography } \\
(\mathrm{n}=62)\end{array}$ & Number & $\%$ \\
\hline $\begin{array}{c}\text { Age }(\text { years }): \\
1-6\end{array}$ & 37 & 59.7 \\
$7-12$ & 11 & 17.7 \\
$13-18$ & 8 & 12.9 \\
$19-50$ & 6 & 9.7 \\
Sex: & & \\
Male & 30 & 48.4 \\
Female & 32 & 51.6 \\
Residence: & & \\
Rural & 38 & 61.3 \\
Urban & 24 & 38.7 \\
\hline
\end{tabular}

Table (2): ECG and Chest X-ray and findings in the studied patients $(n=62)$.

\begin{tabular}{|c|c|c|c|c|c|c|c|}
\hline \multirow{2}{*}{$\begin{array}{l}\text { Investigations } \\
(\mathrm{n}=62)\end{array}$} & \multicolumn{4}{|c|}{ ECG } & \multirow[b]{2}{*}{ Normal } & \multicolumn{2}{|c|}{ Chest X-ray } \\
\hline & RVH & \multicolumn{2}{|c|}{ RAD rsR' } & $\begin{array}{l}\text { RVH+Rt axis } \\
\text { deviation }\end{array}$ & & Cardiomegaly & Normal \\
\hline No. & 8 & 3 & 5 & 4 & 42 & 25 & 37 \\
\hline$\%$ & 12.9 & 4.9 & 8 & 6.4 & 67.7 & 40.3 & 59.9 \\
\hline \multicolumn{8}{|c|}{ RVH: Right ventricular hypertrophy. } \\
\hline \multirow{2}{*}{\multicolumn{2}{|c|}{$\begin{array}{c}\text { Age groups } \\
\text { (ys) }\end{array}$}} & \multicolumn{4}{|c|}{ Children } & & Adults \\
\hline & & \multirow{2}{*}{\multicolumn{2}{|c|}{$\begin{array}{c}{ }^{1}-6 \\
(n=37)\end{array}$}} & ${ }^{7}-12$ & \multirow{2}{*}{\multicolumn{2}{|c|}{$\begin{array}{c}13-18 \\
(n=8)\end{array}$}} & $19-50$ \\
\hline ASD size & & & & $(\mathrm{n}=11)$ & & & $(n=6)$ \\
\hline \multicolumn{8}{|c|}{ TTE: } \\
\hline \multirow{2}{*}{\multicolumn{2}{|c|}{$\begin{array}{l}\text { Range }(\mathrm{mm}) \\
\text { Mean } \pm \mathrm{SD}(\mathrm{mm})\end{array}$}} & \multirow{2}{*}{\multicolumn{2}{|c|}{$\begin{array}{l}(4-24) \\
13.9 \pm 4.8\end{array}$}} & $(6-25)$ & \multirow{2}{*}{\multicolumn{2}{|c|}{$\begin{array}{l}(12-22) \\
14.8 \pm 3.8\end{array}$}} & $(12-32)$ \\
\hline & & & & $13.5 \pm 6.1$ & & & $21.8 \pm 7$ \\
\hline \multicolumn{8}{|l|}{ TEE: } \\
\hline \multicolumn{2}{|c|}{ Range (mm) } & \multicolumn{2}{|c|}{$(6-35)$} & $(8-26)$ & \multicolumn{2}{|c|}{$(17-32)$} & $(15-38)$ \\
\hline \multicolumn{2}{|c|}{ Mean \pm SD $(\mathrm{mm})$} & \multicolumn{2}{|c|}{$16.8 \pm 6.3$} & $17.5 \pm 6.4$ & \multicolumn{2}{|c|}{$23.3 \pm 6.5$} & $26.4 \pm 8.4$ \\
\hline \multicolumn{2}{|l|}{$p$-value } & \multicolumn{2}{|c|}{$0.029^{*}$} & 0.149 & \multicolumn{2}{|c|}{$0.007^{*}$} & 0.327 \\
\hline
\end{tabular}

TTE: Transthoracic echocardiography.

TEE: Transesophageal echocardiography. 
Table (4): Cases with or without cardiomegaly on chest X-ray in relation to the ASD size measured by TTE.

\begin{tabular}{lllllr}
\hline \multirow{2}{*}{ ASD size TTE } & \multicolumn{4}{c}{ Cardiomegaly by CXR } \\
\cline { 2 - 3 } & \multicolumn{2}{c}{ Cases with } & & \multicolumn{2}{c}{ Cases without } \\
\cline { 2 - 3 } \cline { 5 - 6 } & No. & $\%$ & & No. & $\%$ \\
\hline Small $(<5 \mathrm{~mm})(\mathrm{n}=2)$ & None & 0 & & 2 & 100 \\
Moderate $(6-12 \mathrm{~mm})(\mathrm{n}=15)$ & 7 & 46.6 & & 8 & 53.4 \\
Large $(>12 \mathrm{~mm})(\mathrm{n}=45)$ & 37 & 82.2 & & 8 & 17.8 \\
\hline
\end{tabular}

Table (5): Some important procedure characteristics.

\begin{tabular}{|c|c|c|c|c|c|c|c|}
\hline \multirow{2}{*}{$\begin{array}{l}\text { Procedure } \\
\text { characteristics }\end{array}$} & \multicolumn{2}{|c|}{ ASD size $(\mathrm{mm})$} & \multirow{2}{*}{$\begin{array}{c}\text { Device } \\
\text { size } \\
(\mathrm{mm})\end{array}$} & \multirow{2}{*}{$\begin{array}{c}\text { Device/ } \\
\text { defect } \\
\text { ratio }\end{array}$} & \multirow{2}{*}{$\begin{array}{l}\text { Delivery } \\
\text { sheath } \\
\text { diameter } \\
(\mathrm{Fr})\end{array}$} & \multirow{2}{*}{$\begin{array}{c}\text { Procedure } \\
\text { time } \\
\text { (min) }\end{array}$} & \multirow{2}{*}{$\begin{array}{c}\text { Fluoro } \\
\text { time } \\
\text { (min) }\end{array}$} \\
\hline & TTE & TTE & & & & & \\
\hline $\begin{array}{l}\text { Range } \\
\text { mean } \pm \text { SD }\end{array}$ & $\begin{array}{l}4-32 \\
15.7 \pm 5.6\end{array}$ & $\begin{array}{l}6-38 \\
183+69\end{array}$ & $\begin{array}{l}9-40 \\
24.1+6.6\end{array}$ & $\begin{array}{l}1.2-1.6 \\
1.53+0.11\end{array}$ & $\begin{array}{l}6-12 \\
93 \pm 1.6\end{array}$ & $\begin{array}{l}10-45 \\
32.7 \pm 12.1\end{array}$ & $\begin{array}{l}3.2-24 \\
8.4 \pm 4.5\end{array}$ \\
\hline
\end{tabular}

Table (6): Relation between ASD size measured by TEE, TTE and the device closure size.

\begin{tabular}{lll}
\hline & ASD size by TEE & ASD size by TEE \\
\hline ASD size by TEE & & \\
$r$-value & & \\
$p$-value & & \\
ASD size by TTE & & \\
$r$-value & 0.854 & \\
$p$-value & $0.000^{*}$ & \\
Device closure size & & 0.650 \\
$r$-value & 0.764 & $0.000^{*}$ \\
$p$-value & $0.000^{*}$ & \\
\hline
\end{tabular}

\section{Discussion}

We studied 62 patients with significant secundum ASD suitable for device closure [56 (90.4\%) children and $6(9.6 \%)$ adults], 30 males $(48.4 \%)$ and 32 females $(51.6 \%)$. The age of the studied patients ranged from $1-18$ years $(6.1 \pm 3.8$ years $)$ in children and from $19-50$ years $(26 \pm 12.7$ years) in adults. Most of the children patients 37/62 (59.7\%) aged from 1-6 years, 11/62 (17.7\%) aged from 7 12 years and $8 / 62(12.9 \%)$ aged from $13-18$ years in addition to six adults (9.7\%) aged from 19-50 years.

Previous studies reported that transcatheter closure of ASD is efficient in children weighing $\leq 15 \mathrm{Kg}$, and can be proposed as a first line of treatment in symptomatic patient $[\mathbf{7 , 8 ]}$. Choi et al., [9] and Woods et al., [10] stated that device closure is a safer and more effective alternative to surgery, with valid advantages in very small children, including infants and those who weigh $<10 \mathrm{~kg}$ and there was no additional risk in such small babies for transcatheter ASD closure.
Rao and Harris [11] stated that small defects $<5 \mathrm{~mm}$ are likely to spontaneously close and do not need occlusion. Evidence for right ventricular volume overloading (dilatation of right atrium and right ventricle with flat or paradoxical interventricular septal motion) by echocardiogram is used by most cardiologists as an indication for closure. If cardiac catheterization is performed, QP: QS (pulmonary to systemic flow ratio) $>1.5$ is an indication for closure.

In the present study ASD size was measured by TTE before the procedure and by TEE within the procedure and under general anaesthesia. The mean \pm SD ASD size in the patients was $15.7 \pm 5.6$ $\mathrm{mm}$ (measured by TTE) and $18.3 \pm 6.9 \mathrm{~mm}$ (measured by TEE). It was significantly higher when measured by TEE $(13.9 \pm 4.8$ and $14.8 \pm 3.8)$ than when measured by TTE $(16.8 \pm 6.3$ and $23.3 \pm 6.5)$ in the group of children aged (1-6) years and (1318 ) years ( $p=0.029$ and $p=0.007$ respectively). In addition, There was a significant positive correlation between the ASD size that was measured by TTE and that was measured by TEE $(r=0.854, p$ $=0.000$ ). There were significant positive correlations between the ASD size that was measured by TTE and TEE and the size of the ASD device that were used to close the defects ( $r=0.764, p=0.000$ and $r=0.650, p=0.000$ respectively).

In the present study, three types of ASD closure devices were used: Amplatzer septal occluder (ASO) in 57/62 (92\%), Occlutech septal occluder (Figulla-Occlutech Device) (FOD) in 3/62 (5\%) and Amplatzer multifenestrated septal oocluder (cribriform occluder) in 2/62 (3\%). The mean device/defect ratio was $[1.53 \pm 0.11$, (range 1.21.6)]. Successful closure of secundum ASD was achieved in $98.3 \%(61 / 62)$ of patients regarding 
the efficacy (successful closure of the defect without residual shunt) and safety (no deaths or major complications). In one case the device was removed because of complete heart block. Immediate and follow-up results of ASO implantations appear encouraging, with immediate complete closure.

Our results are keeping with Behjati et al., [12] who reported closure rate $94.7 \%$ in their study.

Generally our experience concludes that, closure of secundum ASD was a safe procedure as it was not complicated by death or any of major complications as cerebral embolism, cardiac tamponade, device embolization or dislodgement requiring open cardiac surgery and infectious endocarditis. The patients were discharged 24 hours after the procedure on Aspirin $5 \mathrm{mg} / \mathrm{Kg} /$ day once daily for six months.

\section{Conclusion:}

Transcatheter closure of secundum ASD in children adolescents and adults has a high success rate $(98.3 \%$ ) regarding the efficacy (successful closure of the defect without residual shunt) and safety (no death or major complications as cerebral embolism, cardiac tamponade, device embolization or dislodgement requiring open cardiac surgery and infectious endocarditis) during, immediate and short to midterm follow-up.

It is a safe procedure in young children with small weight (age of 1 year and weight of $10 \mathrm{~kg}$ ), and in adults (age up to 50 years and weight up to $86 \mathrm{Kg})$.

Our findings suggest that Amplatzer device closure of secundum ASD guided by TTE and/or TEE measurements and fluoroscopy could be the first option of management.

\section{Recommendations:}

We recommend further studies on larger number of patients with longer periods of follow-up.

Prompt measurements of ASD size and ASD rims length is achieved by using TTE.

Further studies on the efficacy of TTE as an only modality for assessment of such procedure.

\section{References}

1- SAMANEK M.: Children with congenital heart disease: Probability of natural survival. Pediatr. Cardiol., 13: 152$8,1992$.
2- THERRIEN J. and WEBB G.: Clinical update on adults with congenital heart disease. Lancet, 362: 1305-13, 2003.

3- SAMANEK M. and VORiSKOVA M.: Congenital heart disease among 815,569 children born between 1980 and 1990 and their 15-year survival: A prospective Bohemia survival study. Pediatr. Cardiol., 20: 411-7, 1999.

4- RUDSKI L.G., LAI W.W., AFILALO J., HUA L., HANDSCHUMACHER M.D.,CHANDRASEKARAN K., et al.: Guidelines for the echocardiographic assessmentof the right heart in adults: A report fromthe American Society of Echocardiography. J. Am. Soc. Echocardiogr., 23: 685713, quiz 786-788, 2010.

5- FELTES T.F., BACHA E., BEEKMAN R. 3 rd, CHEATHAM J.P., FEINSTEIN J.A., GOMES A.S., HIJAZI Z.M., ING F.F., DE MOOR M., MORROW W.R., MULLINS C.E., TAUBERT K.A. and ZAHN E.M.: Indications for Cardiac Catheterization and Intervention in Pediatric Cardiac Disease. A Scientific Statement From the American Heart Association. Circulation, 123: 2607-2652, 2011.

6- SILVESTRY F.E., COHEN M.S., ARMSBY L.B., BURKULE N.J., FLEISHMAN C.E., HIJAZI Z.M., LANG R.M., ROME J.J. and WANG Y.: Guidelines for the Echocardiographic Assessment of Atrial Septal Defect and Patent Foramen Ovale: From the American Society of Echocardiography and Society for Cardiac Angiography and Interventions. J. Am. Soc. Echocardiogr. Aug., 28 (8): 910-58, 2015.

7- AL'DZHAMMAZ K.H., BORISOVA N.A., ALEKSANDROV K.I.U., et al.: Results of transcatheter closure of the secundum atrial septal defects in children.Vestn. Khir. Im. II Grek., 167 (5): 51-4, 2008.

8- DALVI B., PINTO R. and GUPTA A.: Device closure of large atrial septal defects requiring devices $>$ or $=20 \mathrm{~mm}$ in small children weighing $<20 \mathrm{~kg}$. Catheter Cardiovasc Interv., 71 (5): 679-86, 2008.

9- CHOI J.Y., KIM N.K., PARK S.J., PARK H.K., PARK Y.H. and SUL J.H.: Feasibility and safety of Transcatheter closure of atrial septal defect in small children weighing $10 \mathrm{~kg}$ or less. Catheter Cardiovasc. Interv., 1: S 10, 2008.

10- WOODS T.D. and PATEL A.: A critical review of patent foramen ovale detection using saline contrast echocardiography: When bubbles lie. J. Am. Soc. Echocardiogr., 19: $215-22,2006$

11-RAO P.S. and HARRIS A.D.: Recent advances in managing septal defects: Atrial Septal Defects. Nov., 22, 6: 2042, 2017.

12- BEHJATI M., MIRHOSSEINI S.J., HOSSEINI S.H. and RAJAEI S.: Transcatheter Closure of Atrial Septal Defect with Amplatzer Device in Children and Adolescents: Short and Midterm results; an Iranian Experience. Iran. J. Pediatr. Jun., 21 (2): 166-72, 2011. 


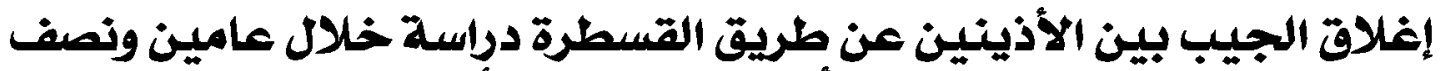

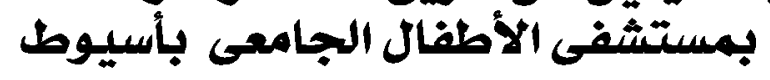

تهدف هذه الدراسة الوصفية المرجعية إلى تقييم سنتين ونصف من الخبرة فى إغلاق الجيب بين الأذينين فى وحدة أمراض القلب للأطفال

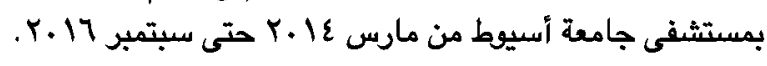
كان المرضى المشمولين فى الدراسة هم الذين خضعوا لإغلاق الجيب بين الأذينين بواسطة جهاز القسطرة القلب وتم أستبعاد أولئك الذين يعانون من ثقب غير مناسب لإغلاثه بواسطة القسطرة وقد أجريت الدراسة من خلال الإل جمع لبيانات التالية: ا- الديموجرافيا الخاصة بالمرضى مثل الأسم، السن، النوع، مكان أقامة المريض، والعلامات الصيوية، والفصص الشامل والقلبى للمريض.

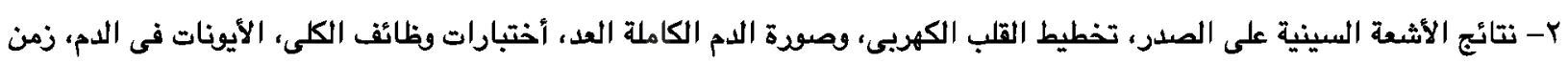

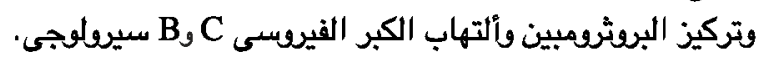

تم تجميع البيانات الكاملة التى تم الحصول عليها عن طريق تخطيط صدرى بالدوبر الملوف مثل حجم الثقب بين الأنينين ونوع الجهاز

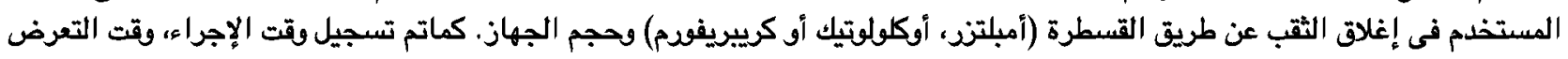

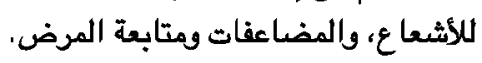

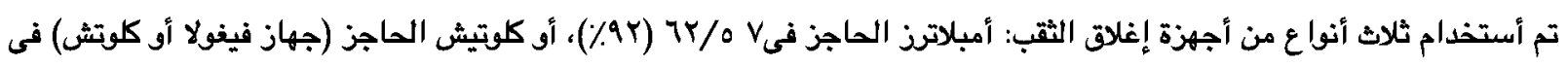

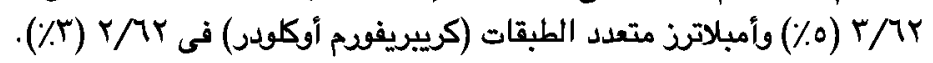

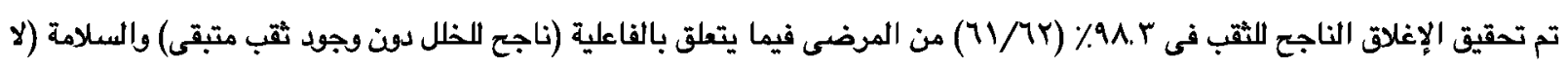

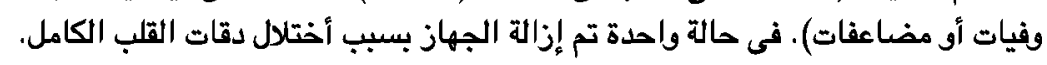

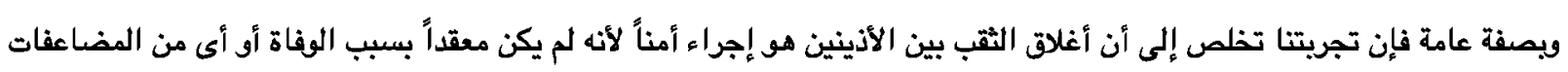

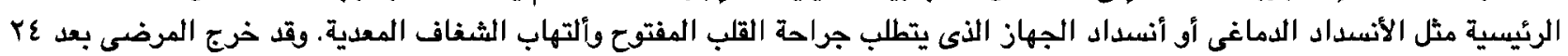

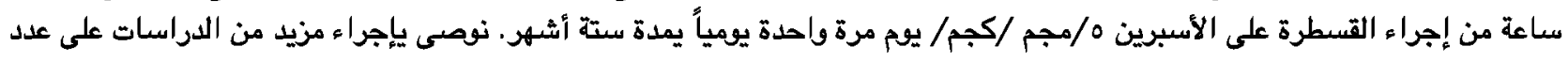

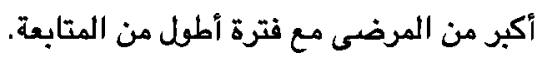

